\title{
Next Generation, Higher Education: Online and blended learning*
}

\author{
Tirtha Goradia \\ Biosciences Endeavour College of Natural Health, Perth, Australia
}

\author{
How to cite this paper: Goradia T. (2019). Next \\ Generation, Higher Education: Online and \\ blended learning*. The Educational Review, \\ USA, 3(7), 75-86. \\ http://dx.doi.org/10.26855/er.2019.07.003
}

*Corresponding author: Tirtha Goradia, Biosciences Endeavour College of Natural Health, Perth, Australia.

Email: Tirtha.goradia@endeavour.edu.au

\begin{abstract}
With advancement in technology, online education has gained popularity in higher education. Many universities are also looking to implement blended courses as a flexible option to learning. With the rise in the next generation learners, implementation of appropriate pedagogies and technologies that suite these learners is highly recommended. This review investigates various trends and innovative ideas for online and blended learning presented in higher education that can be considered as next generation pedagogies. A systematic review was undertaken to explore the trends and the data were evaluated in a descriptive manner. Collectively, the included studies $(n=10)$ revealed innovative ideas for designing courses, implementing curriculum and pedagogies. Strategies that allow flexibility in curriculum, instruction; promote research skills; and provide real-world experience are considered as next generation pedagogies.
\end{abstract}

\section{Keywords}

online learning, blended learning, higher education, next generation, pedagogy

\section{Introduction}

With advances in information technology, online learning has taken a huge leap in the last decade. More and more universities in the higher education sector are now offering online courses providing students with flexibility in their learning pathways. Furthermore, blended learning has been identified as an emerging trend in higher education enhancing interaction and communication between instructors and learners (Nikolaidou et al., 2010). Through these trends, stems the need for appropriate pedagogies that enhance teaching and learning within this space. Additionally, at the turn of the millennium, we are seeing a rise in the set of next generation learners. The next generation learners exhibit unique characteristics. They are comfortable using technologies, like to socialize, and collaborate with peers and prefer hands-on experience. According to Rickes (2016), learning is influenced by cognitive, social and experiential factors and therefore students learn best when they see the content relevant to their lives. The author believes learners build on prior knowledge and collaborate with peers in solving relevant problems. This also resonates with the "Adult learning theory" which researchers believe should be considered while implementing online courses. According to Malcom Knowles's Adult Learning theory (Britt, 2015), adult learners are motivated when learning centers around their experiences and interests; adults being self-directed, the role of the teacher is to facilitate learning instead of knowledge transmission; and adult education must cater to individual differences. Universities are therefore required to constantly review their pedagogies and technologies in order to support the rising generation of adult learners. Witthaus, Rodriquez, Guardia, and Campillo (2016) suggest Intelligent, Distributed, Engaging, Agile and Situated pedagogies (IDEAS) framework for describing next generation pedagogy. This comprises of:

Intelligent pedagogy: Refers to use of various technologies to enhance learning experience for the students.

Distributed pedagogy: Refers to shared ownership of learning components by various stakeholders.

Engaging pedagogy: Refers to a curriculum that makes learning experiences engaging to the students.

Agile pedagogy: Refers to personalized learning pathways allowing flexibility of the curriculum to the learners.

Situated pedagogy: Refers to a curriculum with real-world relevance.

This framework sparked further interest in the area and formed the basis for current review. Previous research in the field of online and blended learning has suggested variety of online teaching practices as well as conceptual frameworks for implementing online courses. This research seeks to explore what the future of online and blended learning would look like and what it means to next generation learners. The aim of this review is to identify trends and innovations in online and 
blended learning and to further evaluate the effectiveness of these trends. Furthermore, the review aims to map the trends to the pedagogies identified within the IDEAS framework. Thus, the main question posed in this systematic review is:

1. What pedagogies support learning of next generation learners?

\section{Methodology}

The protocol for this systematic review was developed using preferred reporting items for systematic reviews and metaanalyses (PRISMA-P) statement (Shamseer et al., 2015)

\subsection{Search strategies}

Studies were identified through searching the following electronic databases: Academic OneFile, ERIC, CINAHL Plus, Psychology Collection and Google Scholar. Following key words were used in various combinations: online learning, blended learning, higher education, best practices, trends, ideas, approach, strategy, module, and framework. EndNote referencing software was used for managing data.

\subsection{Inclusion and exclusion criteria}

The following inclusion criteria were applied: studies that addressed online learning and/or blended learning. Studies were restricted to Higher Education, full text articles, publications from 2008 onwards and peer reviewed journals. Initial screening of titles and abstracts was done followed by screening full-text of studies.

\subsection{Study selection}

While best practices in online teaching are suggested in various articles, only those that provide innovative trends or ideas not yet explored in the literature were included. Qualitative, quantitative, as well as literature review studies were included in this review.

\subsection{Data Extraction}

Data extraction was completed using data extraction table showing following items: Author (year), research methodology, cohort, ideas for online and blended learning in HE, key points, outcomes, statistical validity, bias.

\subsection{Data synthesis}

The review includes studies with different research designs. All studies are manually synthesized to provide a narrative summary of the outcomes.

\subsection{Critical appraisal}

Critical appraisal of the selected articles was done using the 2011 Mixed Methods Appraisal Tool (MMAT) checklist (Pace et al., 2012)

\section{Results}

Using the described methodology, the current review identified 10 relevant papers of which 5 were mixed methods, 1 quantitative study, 1 expert opinion, and 3 qualitative studies (see Figure 1).

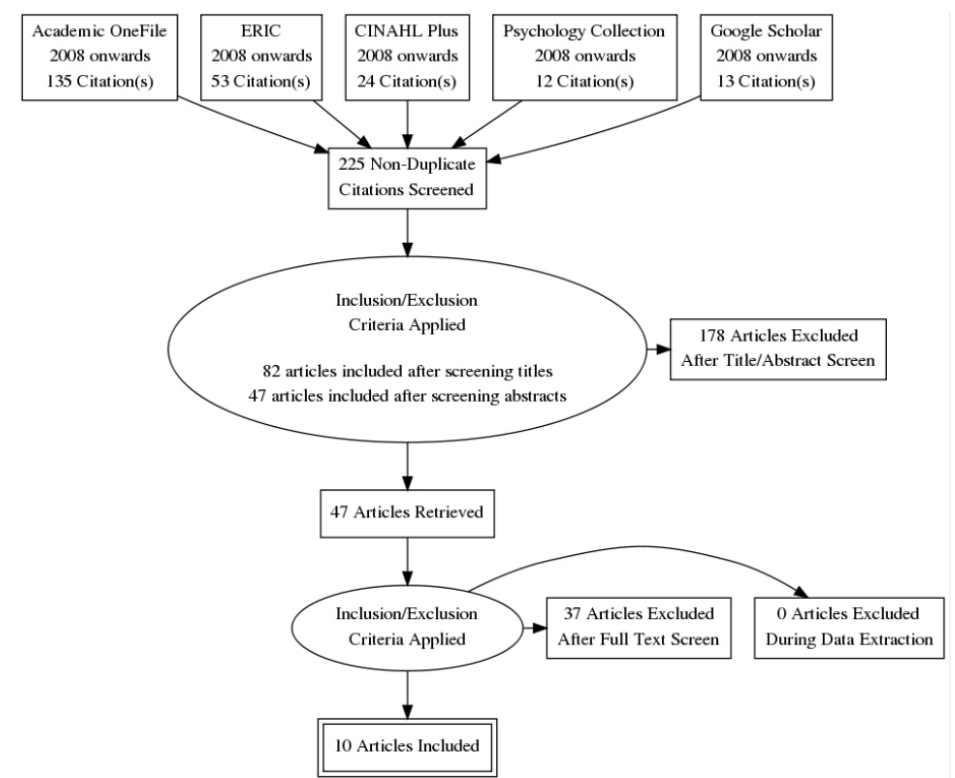

Figure 1. PRISMA flow chart 


\subsection{Risk of bias}

Information on risk of bias was extracted for individual studies. The methodological quality criteria according to the MMAT tool for qualitative, quantitative non-randomized and mixed methods study was applied based on the type of individual study. Five studies (Hayes, Smith, \& Shea, 2015; Jones \& Lau, 2010; Ke \& Xie, 2009; Miyazoe \& Anderson, 2011; Sidebotham, Jomeen, \& Gamble, 2014) present relevant research design and integration of qualitative and quantitative data to answer the research question. Appropriate consideration is given to the limitations of the studies. Therefore, there is low risk of bias associated with these studies.

One study (Svenningsen \& Pear, 2011) recruited participants in a way that minimizes selection bias as these are from the same population. Variables are clearly defined and accurately measured. Dissimilarities between groups that may account for any differences in outcomes are taken into consideration in the data analysis stage. Therefore, there is low risk of bias associated with this study.

Three studies (Khoo \& Cowie, 2011; Malczyk, 2018; Taib \& Holden, 2013) include sources of qualitative data that are relevant to address the research question. Descriptive statistics is used to analyze trends in the data. The research design and findings are relevant to the purpose of the study. Therefore, there is low risk of bias associated with these studies.

High risk of bias is associated with study by Donnelly (2017) as it is a desk-based research study and the findings are based on expert opinion of the authors in the field. Thus, appraisal with MMAT tool indicated low level of bias for 9 studies and moderate level of bias for one study (see Table 1).

Table 1. Data extraction table

\begin{tabular}{|c|c|c|c|c|c|c|c|}
\hline $\begin{array}{l}\text { Author } \\
\text { (year) }\end{array}$ & $\begin{array}{l}\text { Research } \\
\text { methodology }\end{array}$ & Cohort & $\begin{array}{l}\text { IDEAS for Online } \\
\text { and Blended } \\
\text { learning } \mathrm{HE}\end{array}$ & Key points & Outcomes & Statistical validity & Bias \\
\hline $\begin{array}{l}\text { Sidebotham } \\
\text { et al. (2014) }\end{array}$ & $\begin{array}{l}\text { Case report } \\
\text { Mixed methods }\end{array}$ & $\begin{array}{l}\text { Undergraduate } \\
\text { First year } \\
\text { Bachelor of } \\
\text { Midwifery } \\
\text { program }\end{array}$ & $\begin{array}{l}\text { Teaching evidence } \\
\text { based practice and } \\
\text { research through } \\
\text { blended learning }\end{array}$ & $\begin{array}{l}\text { EBPR to be } \\
\text { taught early in } \\
\text { the programme- } \\
\text { year one, } \\
\text { semester two }\end{array}$ & $\begin{array}{l}\text { Positive student } \\
\text { evaluations and } \\
\text { outcomes of the } \\
\text { course. }\end{array}$ & $\begin{array}{l}\text { Pre and post course } \\
\text { evaluations performed; } \\
78 \% \text { students completed } \\
\text { pre course and } 58 \% \text { of } \\
\text { students completed post } \\
\text { course evaluation }\end{array}$ & Low \\
\hline $\begin{array}{l}\text { Hayes et al. } \\
(2015)\end{array}$ & $\begin{array}{l}\text { Case report- } \\
\text { Mixed methods }\end{array}$ & $\begin{array}{l}\text { School of } \\
\text { nursing }\end{array}$ & $\begin{array}{l}\text { Pedagogical } \\
\text { strategies to help } \\
\text { foster regulatory } \\
\text { behaviours in } \\
\text { online learners }\end{array}$ & $\begin{array}{l}\text { Foster regulatory } \\
\text { behaviours in } \\
\text { online learners: } \\
\text { self-regulation, } \\
\text { co-regulation and } \\
\text { shared regulation }\end{array}$ & $\begin{array}{l}\text { Learners' } \\
\text { discourse in the } \\
\text { online learning } \\
\text { environment } \\
\text { demonstrated } \\
\text { each regulation } \\
\text { type within } \\
\text { the Learning } \\
\text { presence (LP) } \\
\text { construct }\end{array}$ & $\begin{array}{l}\text { Inter-rater reliability } \\
\text { (IRR) exceeded } 0.70 \\
\text { Cohort size: } 18 \text { students } \\
435 \text { messages were } \\
\text { analysed quantitatively } \\
\text { and qualitatively }\end{array}$ & Low \\
\hline $\begin{array}{l}\text { Svenningsen } \\
\text { and Pear } \\
(2011)\end{array}$ & Quantitative & $\begin{array}{l}364 \text { First year } \\
\text { university course } \\
\text { that introduces } \\
\text { students to } \\
\text { academic skills }\end{array}$ & $\begin{array}{l}\text { Computer-aided } \\
\text { personalized system } \\
\text { of instruction } \\
\text { in developing } \\
\text { knowledge and } \\
\text { critical thinking in } \\
\text { blended learning } \\
\text { courses }\end{array}$ & $\begin{array}{l}\text { Advanced } \\
\text { students (Peer } \\
\text { reviewers) within } \\
\text { the course to } \\
\text { provide feedback } \\
\text { on unit tests } \\
\text { Students must } \\
\text { demonstrate } \\
\text { mastery on each } \\
\text { study unit before } \\
\text { proceeding to the } \\
\text { next unit } \\
\text { Students can take } \\
\text { CAPSI unit tests } \\
\text { on their own } \\
\text { schedules }\end{array}$ & $\begin{array}{l}\text { The CAPSI } \\
\text { sections } \\
\text { achieved higher } \\
\text { exam scores } \\
\text { than the non- } \\
\text { CAPSI sections } \\
\text { Students in } \\
\text { blended courses } \\
\text { performs well } \\
\text { or better than } \\
\text { students in } \\
\text { strictly lecture- } \\
\text { based courses } \\
\text { CAPSI an } \\
\text { effective } \\
\text { component for } \\
\text { developing } \\
\text { critical thinking } \\
\text { and course } \\
\text { knowledge in } \\
\text { blended designs }\end{array}$ & $\begin{array}{l}\text { Testing against critical } \\
\text { thinking assessment tool } \\
\text { (Applied Critical thinking } \\
\text { measure) } \\
\text { Mean reliability score of } \\
0.85 \text { was obtained } \\
\text { Difference in the final } \\
\text { exam between two } \\
\text { sections } \mathrm{P}=0.053\end{array}$ & low \\
\hline
\end{tabular}


Tabel 1. cont.

\begin{tabular}{|c|c|c|c|c|c|c|c|}
\hline $\begin{array}{l}\text { Author } \\
\text { (year) }\end{array}$ & $\begin{array}{l}\text { Research } \\
\text { methodology }\end{array}$ & Cohort & $\begin{array}{l}\text { IDEAS for Online } \\
\text { and Blended } \\
\text { learning } \mathrm{HE}\end{array}$ & Key points & Outcomes & Statistical validity & Bias \\
\hline $\begin{array}{l}\text { Khoo and } \\
\text { Cowie (2011) }\end{array}$ & $\begin{array}{l}\text { Case study } \\
\text { Qualitative } \\
\text { methodology }\end{array}$ & $\begin{array}{l}\text { New Zealand } \\
\text { tertiary } \\
\text { institution- } \\
\text { graduate course }\end{array}$ & $\begin{array}{l}\text { Framework for } \\
\text { online learning } \\
\text { community. } \\
\text { Framework depicts } \\
\text { learning as a } \\
\text { mediated, situated, } \\
\text { distributed, goal- } \\
\text { directed, and } \\
\text { participatory } \\
\text { activity within } \\
\text { a socially and } \\
\text { culturally } \\
\text { determined learning } \\
\text { community }\end{array}$ & $\begin{array}{l}\text { Participation as } \\
\text { mediated action: } \\
\text { Web-based tools } \\
\text { and activities } \\
\text { as mediational } \\
\text { means; } \\
\text { Participation as } \\
\text { situated activity- } \\
\text { authentic and } \\
\text { relevant activities } \\
\text { Participation } \\
\text { as distributed } \\
\text { cognition- } \\
\text { students access } \\
\text { knowledge, } \\
\text { understanding } \\
\text { and skills } \\
\text { distributed across } \\
\text { the group } \\
\text { Participation as } \\
\text { goal-directed- } \\
\text { goal-directed } \\
\text { learning } \\
\text { activities }\end{array}$ & $\begin{array}{l}\text { Findings showed } \\
\text { evidence of } \\
\text { the value of } \\
\text { mediated, } \\
\text { situated, and } \\
\text { distributed } \\
\text { participation } \\
\text { and shifts in } \\
\text { participant goals }\end{array}$ & $\begin{array}{l}11 \text { out of } 14 \text { students } \\
\text { in the course consented } \\
\text { to participate in the } \\
\text { research; } \\
325 \text { online student } \\
\text { contributions and } \\
83 \text { lecturer online } \\
\text { contributions }\end{array}$ & Low \\
\hline $\begin{array}{l}\text { Ke and Xie } \\
(2009)\end{array}$ & $\begin{array}{l}\text { Mixed methods } \\
\text { study }\end{array}$ & $\begin{array}{l}\text { Nursing, } \\
\text { business } \\
\text { management and } \\
\text { education }\end{array}$ & $\begin{array}{l}\text { Design of } \\
\text { collaborative } \\
\text { learning and } \\
\text { discussion tasks } \\
\text { that reinforce } \\
\text { higher level, deep- } \\
\text { learning-oriented } \\
\text { online interactions }\end{array}$ & $\begin{array}{l}\text { Critical } \\
\text { dimension of } \\
\text { online course } \\
\text { design is the } \\
\text { design of online } \\
\text { discussion tasks } \\
\text { at a deeper level; }\end{array}$ & $\begin{array}{l}\text { Integrated online } \\
\text { course design } \\
\text { models (most } \\
\text { of students' } \\
\text { study time } \\
\text { spent on online } \\
\text { discussions and } \\
\text { team projects) } \\
\text { facilitate highest } \\
\text { satisfaction level } \\
\text { toward learning; } \\
\text { Close-ended } \\
\text { questions depict } \\
\text { lower level of } \\
\text { satisfaction with } \\
\text { online learning }\end{array}$ & $\begin{array}{l}51 \text { students participated } \\
\text { in the study from } 10 \\
\text { online courses; } \\
\mathrm{P}<.05 \text { for all variables }\end{array}$ & Low \\
\hline
\end{tabular}


Tabel 1. cont.

\begin{tabular}{|c|c|c|c|c|c|c|c|}
\hline $\begin{array}{l}\text { Author } \\
\text { (year) }\end{array}$ & $\begin{array}{l}\text { Research } \\
\text { methodology }\end{array}$ & Cohort & $\begin{array}{l}\text { IDEAS for Online } \\
\text { and Blended } \\
\text { learning } \mathrm{HE}\end{array}$ & Key points & Outcomes & Statistical validity & Bias \\
\hline $\begin{array}{l}\text { Jones and } \\
\text { Lau (2010) }\end{array}$ & $\begin{array}{l}\text { Case study } \\
\text { Mixed methods }\end{array}$ & $\begin{array}{l}\text { Courses on } \\
\text { entrepreneurial } \\
\text { skills, business, } \\
\text { management }\end{array}$ & $\begin{array}{l}\text { Institutional } \\
\text { flexibility, credit } \\
\text { accumulation, } \\
\text { transferability } \\
\text { and promote } \\
\text { lifelong learning; } \\
\text { constructivist } \\
\text { pedagogy }\end{array}$ & $\begin{array}{l}\text { Face-to-face } \\
\text { induction for } \\
\text { online learning, } \\
\text { participate on the } \\
\text { discussion board } \\
\text { by completing } \\
\text { induction } \\
\text { exercises, these } \\
\text { formed part of } \\
\text { the students' first } \\
\text { assignment and } \\
\text { the induction } \\
\text { was credit rated, } \\
\text { assigned a } \\
\text { buddy; } \\
\text { Course-multiple } \\
\text { exit routes } \\
\text { Student support- } \\
\text { a single point } \\
\text { of contact } \\
+ \text { weekdays } \\
\text { and weekend } \\
\text { customer } \\
\text { support; } \\
\text { Students were } \\
\text { given the choice } \\
\text { on the amount } \\
\text { of face to face } \\
\text { contact they } \\
\text { required }\end{array}$ & $\begin{array}{l}\text { Supported non- } \\
\text { traditional } \\
\text { students; } \\
\text { Widened } \\
\text { participation, } \\
\text { confidence, }\end{array}$ & $\begin{array}{l}6 \text { further education } \\
\text { colleges worked with the } \\
\text { main university in the } \\
\text { project in Wales }\end{array}$ & Low \\
\hline
\end{tabular}

Taib and

Holden

(2013)

$\begin{array}{ll}\text { Practice report } & \text { Faculties of } \\ \text { Action research } & \text { Business and } \\ \text { Economics and } \\ \text { Qualitative } & \text { information } \\ \text { study } & \text { technology }\end{array}$

A third generation Coming together Small and approach- A

partnership approach to making research and learning skills explicit within the curriculum of first year core units

\section{of non-faculty large group}

staff and

faculty staff;

collaboration

between faculty

academics,

librarians

and learning skills advisers; adaptation of RSD framework discussions provided the potential research and
Action research involved

Low resulting in a consultative feedback on the protocol

mapping process and pointed to impact of these frameworks to explicitly locate learning skills in the first year curriculum, feedback also provided on having a 'oneteam' curriculum design and delivery approach 
Tabel 1. cont.

\begin{tabular}{|c|c|c|c|c|c|c|c|}
\hline $\begin{array}{l}\text { Author } \\
\text { (year) }\end{array}$ & $\begin{array}{l}\text { Research } \\
\text { methodology }\end{array}$ & Cohort & $\begin{array}{l}\text { IDEAS for Online } \\
\text { and Blended } \\
\text { learning } \mathrm{HE}\end{array}$ & Key points & Outcomes & Statistical validity & Bias \\
\hline $\begin{array}{l}\text { Malczyk } \\
(2018)\end{array}$ & $\begin{array}{l}\text { Case study, } \\
\text { Qualitative } \\
\text { methodology }\end{array}$ & $\begin{array}{l}\text { Course on social } \\
\text { policies }\end{array}$ & $\begin{array}{l}\text { Multimodal } \\
\text { instruction- } \\
\text { instructor to prepare } \\
\text { and to offer the } \\
\text { course in multiple } \\
\text { ways each week; } \\
\text { offering the course } \\
\text { on a module-by- } \\
\text { module or lesson- } \\
\text { by-lesson bases } \\
\text { whereby students } \\
\text { can choose their } \\
\text { needed modality } \\
\text { for that week }\end{array}$ & $\begin{array}{l}\text { Provides } \\
\text { students with } \\
\text { the autonomy } \\
\text { to dictate their } \\
\text { own terms of a } \\
\text { blended course; } \\
\text { students in a } \\
\text { multimodal } \\
\text { course choose } \\
\text { on a weekly } \\
\text { basis whether } \\
\text { to participate in } \\
\text { learning activities } \\
\text { synchronously } \\
\text { online, } \\
\text { asynchronously } \\
\text { online, or face to } \\
\text { face }\end{array}$ & $\begin{array}{l}\text { Response to } \\
\text { multimodal } \\
\text { instruction } \\
\text { was positive; } \\
\text { positive student } \\
\text { feedback, } \\
\text { students prefer } \\
\text { the opportunity } \\
\text { to make a } \\
\text { week-by-week } \\
\text { decision about } \\
\text { the modality of } \\
\text { instruction rather } \\
\text { than one time } \\
\text { choice prior to } \\
\text { the beginning of } \\
\text { semester }\end{array}$ & $\begin{array}{l}22 \text { students; randomly } \\
\text { selected to three } \\
\text { groups: fully online, } \\
\text { asynchronous, face to } \\
\text { face and these students } \\
\text { rotated to take each of the } \\
\text { three modalities; } 3 \text { week } \\
\text { period; } 14 / 22 \text { completed } \\
\text { end of experiment survey }\end{array}$ & Low \\
\hline $\begin{array}{l}\text { Miyazoe and } \\
\text { Anderson } \\
(2011)\end{array}$ & $\begin{array}{l}\text { Design-based } \\
\text { research study; } \\
\text { mixed-method } \\
\text { study }\end{array}$ & $\begin{array}{l}\text { Course- } \\
\text { Introduction } \\
\text { to English for } \\
\text { Academic } \\
\text { Purposes }\end{array}$ & $\begin{array}{l}\text { Implementing } \\
\text { discussion forums } \\
\text { and blog writings } \\
\text { using pseudonyms } \\
\text { in blended learning }\end{array}$ & $\begin{array}{l}\text { Anonymity as } \\
\text { a pedagogical } \\
\text { intervention } \\
\text { in writing } \\
\text { instruction; at } \\
\text { the end of the } \\
\text { semester the } \\
\text { students reported } \\
\text { their pseudonyms } \\
\text { to the instructor } \\
\text { for grading } \\
\text { purposes }\end{array}$ & $\begin{array}{l}\text { Higher online } \\
\text { participation; } \\
\text { enhanced } \\
\text { learning } \\
\text { outcomes in } \\
\text { blended learning }\end{array}$ & $\begin{array}{l}63 \text { students participated; } \\
15 \text { students volunteered } \\
\text { for interview; five } \\
\text { data sources used for } \\
\text { triangulation }\end{array}$ & Low \\
\hline
\end{tabular}

\subsection{Outcomes}

Given the heterogeneity of methodology and outcome variables, a meta-analysis was not possible. Considering the objectives of the review, the following outcomes have been identified: 5 studies identified innovative designs. 5 studies identified innovative pedagogies. 2 studies discussed curriculum (see Table 1).

\subsubsection{Designs}

Sidebotham et al. (2014) describes the design of evidence based practice and research (EBPR) course delivered in blended model. Collaborative activities, role play, interactive online modules and assessments formed the core components of the blended course to promote engagement. Two day workshops offered on campus covered core themes and topics related to EBPR. The interactive modules involved discussion on research questions, assessment items and critical analysis of research papers. Although, positive student evaluations and outcomes were achieved at the end of the EBPR course, participant sample size was limited with only 30 participants completing the post-course survey. As well as the pre and post course survey does not provide statistical significance data and therefore the outcomes cannot be generalized. Svenningsen and Pear (2011) through their study indicated Computer-aided personalized system of instruction (CAPSI) as a blended learning design that is a viable option in higher education. CAPSI is a computerized form of personalized instruction that is mediated through use of web-based technology resources. In addition to using web-based tools, CAPSI uses more advanced students within a course to provide feedback on unit tests as opposed to the traditional form of instruction where advanced students from outside the course provide feedback. The statistical evaluation of the results along with large cohort size add reliability and validity to the findings of the study and the course design. Study findings from Ke and Xie (2009) indicate an integrated online course model that promotes highest learning satisfaction and deep learning. Within such a model, content is fluid and not structured and most of students' study time is spent on online discussions and team projects. The course design included introductory readings, interactive discussions for content comprehension followed by collaborative assignments. The statistical analysis as 
well as descriptive analysis of the results strongly support the outcomes of the study. Blended course design by Jones and Lau (2010) widened participation in higher education by allowing institutional flexibility and promoting opportunities for lifelong learning. The course offered credit rated face-to-face induction sessions for online learning, multiple exit routes within the credit framework, weekdays and weekend student support as well as flexibility allowing students to choose the amount of face to face contact they required. These factors paved ways for lifelong learning by emphasizing on institutional flexibility, credit accumulation and transferability. The students identified improvement in their knowledge and skills which in turn increased self-efficacy and personal satisfaction. Malczyk (2018) proposed a multimodal instruction blended course design that offered the course in multiple ways providing students with the autonomy to dictate their own terms of a blended course. Students in a multimodal instruction choose on a weekly basis whether to participate in learning activities synchronously online, asynchronously online, or face to face. The response to this form of course design was positive whereby students preferred the opportunity to make weekly decisions about the modality of instruction rather than one time selection at the start of semester.

Overall, the course designs enhanced learning satisfaction amongst students and increased academic outcomes. Studies included mixed methods, quantitative and qualitative methodologies and low bias was indicated for these studies. Mapping to IDEAS framework, most of these designs correlated to agile pedagogy where the designs provide flexibility and customization of the course and the student experience.

\subsubsection{Evidence-based practice through blended learning}

The innovative idea highlighted in this review was evidence based practice being taught through a blended learning module. Wide range of professions and in particular health professions are transitioning to evidence-based practice (EBP). Educational institutions are now offering an EBP curriculum in the face-to-face environment. However, the training in this area seems to be insufficient as well as the learning outcomes. Educators are therefore investigating the role of blended learning module in teaching evidence-based practice. The EBPR course design through blended learning suggested in this review by Mary, Julie, and Jennifer (2014) revealed positive student evaluations and outcomes. The review conducted by Rohwer, Motaze, Rehfuess, Young, and Campbell (2017) revealed blended learning had positive impact on evidence based health care knowledge, skills, attitude and behavior when compared with face-to-face learning and only e-learning. Similarly, a randomized controlled trial of a blended learning education intervention for teaching evidence-based medicine revealed increasing medical students' attitude towards EBM and use in clinical practice (Ilic, Nordin, Glasziou, Tilson, \& Villanueva, 2015). The study however, did not see significant improvement in students' knowledge and skills in EBM when compared to didactic learning approach of teaching. Overall, blended learning as a design seems to be a promising next generation pedagogy.

\subsubsection{Personalized system of instruction through online and blended learning}

Keller's personalized system of instruction (PSI) was introduced in the late 1960s (Eyre, 2007). With PSI, students progress through the course at their own pace and are required to demonstrate mastery on each study unit before proceeding to the next unit, peer reviewers within the course are to provide individualized feedback on unit tests and students can take the tests on their own schedule (Price, 2000; Svenningsen \& Pear, 2011). Computer and internet technology has now enabled to create PSI programs such as computer-aided personalized system of instruction (CAPSI). CAPSI seems to be compatible with a blended learning approach (Svenningsen \& Pear, 2011) whereby, online and blended learning designs have changed the traditional role of lecturer into that of a facilitator (Eyre, 2007). Similarly, various other web technologies through online and blended learning designs have allowed delivery of learning resources along with individualized assessment system to cater to individual students (Gok, 2010; Kim, Olfman, Ryan, \& Eryilmaz, 2014). These studies have shown to enhance students' problem solving skills as well as self-directed learning abilities. Thus relating to the IDEAS framework, these pedagogies and technologies relate to agile pedagogy whereby the PSI through online and blended learning modules offers personalized learning pathways to students, individual learning support, and a flexible curriculum. This innovative trend lays foundation for the next generation learning.

\subsubsection{Flexibility in instruction}

Innovative course designs suggested in three studies highlighted flexibility in course structure and delivery. The online course design adopted by Ke and Xie (2009) in their study incorporated a fluid course content along with collaborative activities and online discussions. The findings in this study revealed greater learner satisfaction and academic performance. Jones and Lau (2010) presented a flexible institutional model that encompassed open entry policy, full degree programs as well as staged awards in the forms of certificate programs, credit rated modules and multiple exit routes. The teaching and learning delivered through this blended learning module contributed to widening participation, entrepreneurship and lifelong learning. Another flexible mode of instruction is presented in the study conducted by Malczyk (2018). According to the author the multimodal instruction enhances student autonomy by allowing them to select their own terms of blended course in terms of participating in activities synchronously online, asynchronously online, or face-to-face. Thus, these innovative trends align with agile pedagogy as suggested in the IDEAS framework and form an important aspect of next generation pedagogy in higher education. Educators and institutions are moving away from the traditional 'one size fits all' approach to a more customized approach providing students with wide range of learning options and support. Next generation online and blended learning pedagogy will provide new horizons in the development of higher education. 


\subsubsection{Pedagogies}

Five studies (see Table 2) suggest innovative pedagogies that promote a strong online learning community thereby highlighting the importance of constructive pedagogy. Studies are mixed methods and qualitative studies. Low bias was indicated for 4 studies and moderate bias indicated for 1 study. Mapping to IDEAS framework, most of these pedagogies correlate to distributed pedagogy, engaging pedagogy and situated pedagogy that accounts for distributed ownership of various learning components by actively engaging students to solve real-world problems. The studies highlight the importance of a strong online learning community to enhance teaching and learning in this space. According to Speily and Kardan (2018), online learning community is a kind of learning platform where learners with common goals come together and share knowledge without having any restriction of time and space. Effective online practices foster interactions that support learners socially and academically

\section{Table 2. Summary of innovative pedagogies identified in this review.}

\begin{tabular}{ll}
\hline Author/Study & Pedagogy \\
\hline Hayes et al. (2015) & $\begin{array}{l}\text { Study findings demonstrate pedagogical strategies to promote self-regulation, co-regulation } \\
\text { and shared regulation in the online learning environment }\end{array}$ \\
Proposes blended problem-based learning as a transformative strategy based on socio- \\
technological network \\
Pedagogical strategies that introduce authentic, relevant, goal-directed learning activities \\
within a framework for online learning community. The framework depicts learning as a \\
mediated, situated, distributed, goal-directed, and participatory activity within a socially and \\
culturally determined learning community \\
Khoo and Cowie (2011)
\end{tabular}

\subsubsection{Distributed pedagogy}

The concept of distributed ownership is highlighted in this review. It includes collaboration between learners, institutions, and teachers. As participants interact with each other, they share and create a new understanding of knowledge that would otherwise be difficult for an individual (Khoo \& Cowie, 2011). This aligns with Vygotsky's social constructivist theory. According to this theory, social interaction is fundamental in the development of cognition as learners co-construct knowledge (Mahn, 1999). Pedagogical strategies that foster self-regulation, co-regulation and shared regulation between learners as well as pedagogies such as collaborative learning enhance interactions between students thereby creating a strong online learning community. As such, the online teacher plays an important role in facilitating the communications. Additionally, study presented by Miyazoe and Anderson (2011) revealed improvement in writing skills through collaborative revision. In this study, students interacted with peers in text revision towards the final drafts. Within the IDEAS framework of distributed pedagogy, ownership for different components of the learning journey is distributed to various stakeholders.

\subsubsection{Situated pedagogy}

IDEAS framework suggests situated pedagogy as the next generation pedagogy that emphasizes the need for curricula with real-world relevance. The framework highlights the importance of providing students with work-related opportunities and experience through project and problem-based learning (PBL). Aligned with this suggestion, the current review identified 2 studies that discussed incorporation of authentic, relevant activities to enhance learning. Khoo and Cowie (2011) suggests selection of authentic and relevant tasks to depict real-life research issues and establish collaboration with peers. The authors believe such activities are likely to foster student interaction and contribute to the development of a collaborative online community. Similarly, Donnelly (2017) suggests blended problem-based learning meets the need for creating authentic learning environments. The author believes a socio-technological model such as blended PBL promotes active learning and enhances the learner's autonomy, self-esteem and intrinsic motivation to learn. Thus, situated pedagogy will allow next generation learners to identify and solve issues relevant to their industry and society.

\subsubsection{Curriculum}

2 studies in this review identified innovative trends in the area of curriculum. The 2 studies highlight the importance of research skills early on in the degree courses. The studies included mixed methods and action research study. Low bias was indicated for both the studies. The concept of introducing research courses early in the curriculum has been controversial in 
the undergraduate setting. However, much emphasis is now laid on evidence based practice and therefore the importance of research skills. In particular, health profession is undergoing a major overhaul by shifting from traditional-based practice to evidence-based practice. Sidebotham et al. (2014) emphasize evidence based practice and research skills in undergraduate degree programs within the curriculum of first year units. Traditionally, students find EBP courses challenging. However, the positive outcomes of the study validate the decision to introduce evidence based practice research course early on. The course was introduced through blended learning module. Not only did the students appreciate the need to practice within an evidence based framework, but also sparked an enthusiasm for becoming actively involved in research. Additionally, the blended learning module enhanced student engagement and yielded a sense of satisfaction. Similar to this study, Taib and Holden (2013) emphasize a partnership approach to making research and learning skills explicit within the curriculum of first year units. The partnership model is informed by the Research Skills Development (RSD) Framework. RSD framework is intended to inform curriculum and assessment design to promote research skills across a student's educational lifetime (Willison \& O'Regan, 2007). The framework conceptualizes research skill development in early years of undergraduate studies in order to provide quality researchers to deal with the challenges of $21^{\text {st }}$ century. To that end, the partnership model in this review involves pedagogical conversations between teaching faculty, learning skills advisers and librarians. It highlights shared responsibility and collaboration between non-faculty staff such as librarians and learning skills advisors, and academic staff.

Mapping to IDEAS framework, the ideas suggested in these 2 studies correlate to distributed pedagogy referring to shared ownership of learning components as well as situated pedagogy where learners solve real-world problems through scholarly research. Thus next generation pedagogy within higher education will envisage growth in research development and blended learning could probably augment this learning process.

\section{Discussion}

The aim of this review was to identify trends and innovations in online and blended learning that suit next generation adult learners. To that end, the study presented innovative ideas that can be used to implement designs, pedagogies and curriculum in higher education. The findings of this study align with the adult learning theory whereby the designs, pedagogies and curriculum are known to enhance learner's autonomy, self-efficacy, intrinsic motivation, satisfaction and academic performance in the online environment. Students achieved better understanding of course knowledge and received higher grades in their assessments. This reveals that students not only were satisfied by the strategies but they also exhibited enhanced learning. The review highlights the importance of having a curriculum with real-world relevance, also called as experiential learning. By allowing research skill development at an early on period and incorporating problem-based learning, learners are able to actively participate in research activities enabling them to solve problems in real context. Collaborating with peers to seek real-world solutions seems to be the way going forwards. Learners are able to socialize and actively participate in the learning process as opposed to passively receive information from teachers. The innovative ideas discussed in this study inform planning of next generation online and blended learning in higher education. The review also aimed to map the trends to the pedagogies identified within the IDEAS framework. To that end, the review identified innovative approaches in online and/or blended learning which point to next-generation pedagogy. These are:

Distributed pedagogy: Educators believe the role of teachers is to enable students to learn how to learn and take responsibility for their own learning (Johnson et al., 2009). Condie and Livingston's study (2007, as cited in (Johnson et al., 2009) describes this as having the ability to create an effective learning environment whereby students are actively engaged in the learning process thus developing a sense of ownership. These concepts resonate with self-regulated learning which is central to online learning. Online learning requires students to possess self-generated ability to control, manage, and plan their learning actionsoverall engage in a regulatory process, referred to as 'self-regulated learning' (Zimmerman, 1989, as cited in (Goradia \& Bugarcic, 2017). Thus, while current research and theories discuss individual ownership, this review highlights distributed ownership as the next generation pedagogy central to online learning. The concept of shared ownership of learning between various stakeholders is well appreciated in this review. A partnership model allows collaboration between teaching and nonteaching staff with the teaching staff focusing on curriculum and non-teaching staff focusing on skill development and providing learner support. As well as the importance of online learning community is highlighted in this review. Pedagogies that enforce self-regulation and shared regulation between learners are encouraged in the online environment. Pedagogies that enhance interactions and communications to promote deeper learning of content are recognized in this review.

Agile pedagogy: The concept of allowing flexibility in learning and providing personalized learning pathways is well appreciated in this review. Modules and assessments that students can take at their own pace, a flexible unit structure as opposed to a rigid structure, and computer-aided personalized system of support are some of the highlights in this review. These pedagogies widen participation in higher education and pave ways for lifelong learning. Although this pedagogy does not support 'one size fits all' approach, the suggested customized approach may encounter challenges in its implementation. This requires policy makers, institutions as well as academics to make necessary changes in the online delivery process.

Situated pedagogy: The concept of including a curriculum with real-world relevance is well portrayed in this review. The review informs course co-coordinators and institutions to promote scholarly research to solve real-world problems. The IDEAS 
framework suggests providing work-relating opportunities for students in accordance with their professional and personal goals. Thus, this review aimed to answer the research question: What pedagogies support next generation learners? In doing so, the identified pedagogies provide strategic framework towards the planning for the future of online and blended higher education. The innovative ideas will enable online and blended higher education to widen student participation and prepare students for lifelong learning. This study suggests educational institutions to explore innovative practices that support learning of next generation learners. Collectively, a change at institutional level and involvement of multiple stakeholders is essential to address the needs of next generation learners.

\section{Limitation}

Few studies had small sample sizes. 1 study was based on expert opinion. More rigorous research design and comparison group is essential to contribute to reliability and validity of the outcomes. In spite of these limitations, the review provides an invaluable insight into future planning of online and blended courses in higher education.

\section{Conclusion}

This review identified next generation pedagogies, the new trends, suggested for online and blended learning in higher education. With widening participation, student engagement, improved learning outcomes and student autonomy, the next generation pedagogies mediated through technologies seem promising. The trends support student centricity paving ways for lifelong learning. This has implications for academics, administrators, educational institutions as well as policy makers seeking to improve the online and blended learning pathways in higher education. Further research is essential in evaluating whether the course designs, pedagogies and curricula suggested in this review will be effective in various discipline and institutional settings.

\section{Acknowledgements}

The author wishes to thank library staff for assistance with proof reading of the article.

\section{Funding}

This research did not receive any specific grant from funding agencies in the public, commercial, or not-for-profit sectors.

\section{References}

Britt, M. (2015). How to Better Engage Online Students with Online Strategies. College Student Journal, 49(3), 399-404.

Donnelly, R. (2017). Blended problem-based learning in higher education: The intersection of social learning and technology. Psychosociological Issues in Human Resource Management, 5, 25+.

Eyre, H. L. (2007). Keller's Personalized System of Instruction: Was It a Fleeting Fancy or Is There a Revival on the Horizon? Behavior Analyst Today, 8(3), 317-324.

Gok, T. (2010). Using Computer-Assisted Personalized Assignment System in a Large-Enrollment General Physics. European Journal of Physics Education, 1(1), 28-43.

Goradia, T., \& Bugarcic, A. (2017). A social cognitive view of self-regulated learning within online environment. Advances in Integrative Medicine, 4(1), 5-6. doi:10.1016/j.aimed.2017.05.001

Hayes, S., Smith, S. U., \& Shea, P. (2015). Expanding learning presence to account for the direction of regulative intent: self-, co- and shared regulation in online learning. Online Learning Journal (OLJ), 19, 15+.

Ilic, D., Nordin, R. B., Glasziou, P., Tilson, J. K., \& Villanueva, E. (2015). A randomised controlled trial of a blended learning education intervention for teaching evidence-based medicine. BMC Medical Education, 15, 39-39. doi:10.1186/s12909-015-0321-6

Johnson, N., List-Ivankovic, J., Eboh, W., Ireland, J., Adams, D., Mowatt, E., \& Martindale, S. (2009). Research and evidence based practice: Using a blended approach to teaching and learning in undergraduate nurse education (Vol. 10).

Jones, N., \& Lau, A. M. S. (2010). Blending Learning: Widening Participation in Higher Education. Innovations in Education and Teaching International, 47(4), 405-416.

Ke, F., \& Xie, K. (2009). Toward Deep Learning for Adult Students in Online Courses. Internet and Higher Education, 12(3), $136-145$.

Khoo, E., \& Cowie, B. (2011). A Framework for Developing and Implementing an Online Learning Community. Journal of Open, Flexible and Distance Learning, 15(1), 47-59.

Kim, R., Olfman, L., Ryan, T., \& Eryilmaz, E. (2014). Leveraging a personalized system to improve self-directed learning in online educational environments. Computers \& Education, 70, 150-160. doi:10.1016/j.compedu.2013.08.006

Mahn, H. (1999). Vygotsky's Methodological Contribution to Sociocultural Theory. Remedial \& Special Education, $20(6), 341$. doi: $10.1177 / 074193259902000607$ 
Malczyk, B. R. (2018). Multimodal Instruction, the New Hybrid: A Student-Centered Approach to Blended Learning. Journal of Nonprofit Education and Leadership, 8, 16+.

Miyazoe, T., \& Anderson, T. (2011). Anonymity in blended learning: who would you like to be? Educational Technology \& Society, 14, 175+.

Nikolaidou, M., Sofianopoulou, C., Alexopoulou, N., Abeliotis, K., Detsis, V., Chalkias, C., .. . Anagnostopoulos, D. (2010). The blended learning ecosystem of an academic institution in Greece. International Journal of Web-Based Learning and Teaching Technologies, 5, 14+.

Pace, R., Pluye, P., Bartlett, G., Macaulay, A. C., Salsberg, J., Jagosh, J., \& Seller, R. (2012). Testing the reliability and efficiency of the pilot Mixed Methods Appraisal Tool (MMAT) for systematic mixed studies review. Int J Nurs Stud, 49(1), 4753. doi:10.1016/j.ijnurstu.2011.07.002

Price, R. V. (2000). PSI Revisited: Designing College Courses Using the Personalized System of Instruction (PSI) Model. Retrieved from https://login.ezproxy.endeavour.edu.au:2443/login?url=http://search.ebscohost.com/login.aspx?direct=true\&db $=$ eric $\& \mathrm{AN}=\mathrm{ED} 442324 \&$ site $=$ eds-live $\&$ scope $=$ site

Rickes, P. C. (2016). Generations in flux How Gen Z will continue to transform higher education. Planning for Higher Education, 44(4), 21-45.

Rohwer, A., Motaze, N. V., Rehfuess, E., Young, T., \& Campbell, C. (2017). E-Learning of Evidence-Based Health Care (EBHC) in Healthcare Professionals: A Systematic Review. Campbell Systematic Reviews 2017:4: Campbell Collaboration.

Shamseer, L., Moher, D., Clarke, M., Ghersi, D., Liberati, A., Petticrew, M., . . Group, P.-P. (2015). Preferred reporting items for systematic review and meta-analysis protocols (PRISMA-P) 2015: elaboration and explanation. BMJ, 349 , g7647. doi:10.1136/bmj.g7647

Sidebotham, M., Jomeen, J., \& Gamble, J. (2014). Teaching evidence based practice and research through blended learning to undergraduate midwifery students from a practice based perspective. Nurse Education in Practice, 14(2), $220-224$. doi:10.1016/j.nepr.2013.10.001

Speily, O. R. B., \& Kardan, A. A. (2018). Increasing Information Reposting Behavior in Online Learning Community. Journal of Educational Technology \& Society, 21(4), 100-110.

Svenningsen, L., \& Pear, J. J. (2011). Effects of computer-aided personalized system of instruction in developing knowledge and critical thinking in blended learning courses. The Behavior Analyst Today, 12, 33+.

Taib, A., \& Holden, J. (2013). "Third generation" conversations--a partnership approach to embedding research and learning skills development in the first year. A practice report. The International Journal of the First Year in Higher Education, 4, 131+.

Willison, J., \& O’Regan, K. (2007). Commonly known, commonly not known, totally unknown: a framework for students becoming researchers. Higher Education Research \& Development(4), 393. doi:10.1080/07294360701658609

Witthaus, G., Rodriquez, B. C. P., Guardia, L., \& Campillo, C. G. (2016). Next generation pedagogy: Ideas for online and blended higher education. Retrieved from

Britt, M. (2015). How to Better Engage Online Students with Online Strategies. College Student Journal, 49(3), 399-404.

Donnelly, R. (2017). Blended problem-based learning in higher education: The intersection of social learning and technology. Psychosociological Issues in Human Resource Management, 5, 25+.

Eyre, H. L. (2007). Keller's Personalized System of Instruction: Was It a Fleeting Fancy or Is There a Revival on the Horizon? Behavior Analyst Today, 8(3), 317-324.

Gok, T. (2010). Using Computer-Assisted Personalized Assignment System in a Large-Enrollment General Physics. European Journal of Physics Education, 1(1), 28-43.

Goradia, T., \& Bugarcic, A. (2017). A social cognitive view of self-regulated learning within online environment. Advances in Integrative Medicine, 4(1), 5-6. doi:10.1016/j.aimed.2017.05.001

Hayes, S., Smith, S. U., \& Shea, P. (2015). Expanding learning presence to account for the direction of regulative intent: self-, co- and shared regulation in online learning. Online Learning Journal (OLJ), 19, 15+.

Ilic, D., Nordin, R. B., Glasziou, P., Tilson, J. K., \& Villanueva, E. (2015). A randomised controlled trial of a blended learning education intervention for teaching evidence-based medicine. BMC Medical Education, 15, 39-39. doi:10.1186/s12909-015-0321-6

Johnson, N., List-Ivankovic, J., Eboh, W., Ireland, J., Adams, D., Mowatt, E., \& Martindale, S. (2009). Research and evidence based practice: Using a blended approach to teaching and learning in undergraduate nurse education (Vol. 10).

Jones, N., \& Lau, A. M. S. (2010). Blending Learning: Widening Participation in Higher Education. Innovations in Education and Teaching International, 47(4), 405-416.

Ke, F., \& Xie, K. (2009). Toward Deep Learning for Adult Students in Online Courses. Internet and Higher Education, 12(3), $136-145$. 
Khoo, E., \& Cowie, B. (2011). A Framework for Developing and Implementing an Online Learning Community. Journal of Open, Flexible and Distance Learning, 15(1), 47-59.

Kim, R., Olfman, L., Ryan, T., \& Eryilmaz, E. (2014). Leveraging a personalized system to improve self-directed learning in online educational environments. Computers \& Education, 70, 150-160. doi:10.1016/j.compedu.2013.08.006

Mahn, H. (1999). Vygotsky's Methodological Contribution to Sociocultural Theory. Remedial \& Special Education, $20(6), 341$. doi:10.1177/074193259902000607

Malczyk, B. R. (2018). Multimodal Instruction, the New Hybrid: A Student-Centered Approach to Blended Learning. Journal of Nonprofit Education and Leadership, 8, 16+.

Mary, S., Julie, J., \& Jennifer, G. (2014). Teaching evidence based practice and research through blended learning to undergraduate midwifery students from a practice based perspective. Nurse Education in Practice, 14(2), 220-224. doi:10.1016/j.nepr.2013.10.001

Miyazoe, T., \& Anderson, T. (2011). Anonymity in blended learning: who would you like to be? Educational Technology \& Society, 14, 175+.

Nikolaidou, M., Sofianopoulou, C., Alexopoulou, N., Abeliotis, K., Detsis, V., Chalkias, C., .. . Anagnostopoulos, D. (2010). The blended learning ecosystem of an academic institution in Greece. International Journal of Web-Based Learning and Teaching Technologies, 5, 14+.

Pace, R., Pluye, P., Bartlett, G., Macaulay, A. C., Salsberg, J., Jagosh, J., \& Seller, R. (2012). Testing the reliability and efficiency of the pilot Mixed Methods Appraisal Tool (MMAT) for systematic mixed studies review. Int J Nurs Stud, 49(1), 4753. doi:10.1016/j.ijnurstu.2011.07.002

Price, R. V. (2000). PSI Revisited: Designing College Courses Using the Personalized System of Instruction (PSI) Model. Retrieved from https://login.ezproxy.endeavour.edu.au:2443/login?url=http://search.ebscohost.com/login.aspx?direct=true\&db $=$ eric $\& A N=$ ED442324\&site $=$ eds-live \&scope $=$ site

Rickes, P. C. (2016). Generations in flux How Gen Z will continue to transform higher education. Planning for Higher Education, 44(4), 21-45.

Rohwer, A., Motaze, N. V., Rehfuess, E., Young, T., \& Campbell, C. (2017). E-Learning of Evidence-Based Health Care (EBHC) in Healthcare Professionals: A Systematic Review. Campbell Systematic Reviews 2017:4: Campbell Collaboration.

Shamseer, L., Moher, D., Clarke, M., Ghersi, D., Liberati, A., Petticrew, M., . . . Group, P.-P. (2015). Preferred reporting items for systematic review and meta-analysis protocols (PRISMA-P) 2015: elaboration and explanation. BMJ, 349, g7647. doi:10.1136/bmj.g7647

Speily, O. R. B., \& Kardan, A. A. (2018). Increasing Information Reposting Behavior in Online Learning Community. Journal of Educational Technology \& Society, 21(4), 100-110.

Svenningsen, L., \& Pear, J. J. (2011). Effects of computer-aided personalized system of instruction in developing knowledge and critical thinking in blended learning courses. The Behavior Analyst Today, 12, 33+.

Taib, A., \& Holden, J. (2013). "Third generation" conversations--a partnership approach to embedding research and learning skills development in the first year. A practice report. The International Journal of the First Year in Higher Education, 4, 131+.

Willison, J., \& O’Regan, K. (2007). Commonly known, commonly not known, totally unknown: a framework for students becoming researchers. Higher Education Research \& Development(4), 393. doi:10.1080/07294360701658609

Witthaus, G., Rodriquez, B. C. P., Guardia, L., \& Campillo, C. G. (2016). Next generation pedagogy: Ideas for online and blended higher education. Retrieved from http://openaccess.uoc.edu/webapps/o2/bitstream/10609/51441/1/Next_Generation_ Pedagogy.pdf 